\title{
O CANIBALISMO ASTECA: RELEITURA E DESDOBRAMENTOS
}

Oscar Calavia Sáez

\section{Polêmicas}

Os astecas ${ }^{1}$ abriram, nos idos de 1977, o debate sobre o canibalismo na antropologia contemporânea. Foi nesse ano que Michael Harner publicou um artigo que interpretava a máquina de guerra do México-Tenochtitlan e o canibalismo em grande escala, que estaria associado a ela, como um recurso para compensar a falta de proteína que afligia a densa população do império mexica, desprovido de caça ou gado de grande porte. As adesões à tese de Harner e as posteriores refutações a ela (cf. Harris 1977; Ortiz de Montellano 1978; Sahlins 1978, 1979) avolumaram uma controvérsia cujas sequelas duram até os dias de hoje. Mas os astecas saíram logo dessa disputa que tinham originado, e apenas foram citados após os primeiros embates. Inspiraram poucas páginas dos desconstrutores do canibalismo e nenhuma dos etnólogos que, especialmente a partir do caso Tupi, proporcionaram um pouco depois um notável desenvolvimento à velha matéria antropofágica, em especial no Brasil - ausência lamentável em um e outro caso, porque os dados mexicanos poderiam ter para ambos um valor crítico.

À distância de mais de trinta anos, a tese de Harner parece demasiado afoita. Já em pleno século XVI, Francisco Hernández, protomédico de Felipe II (Hernández 2000:115), admirava-se com a fartura dos mercados do México e, concretamente, com a sua variada oferta de carnes nativas. Nas mesmas páginas dos cronistas e dos missionários em que Harner encontrou seus argumentos, encontram-se os contra-argumentos que ele desconsiderou, pois nelas abundam as referências aos cadáveres que se decompunham no campo de batalha e ao desperdício das proteínas obtidas em muitos dos rituais sacrificiais, cujas vítimas eram destruídas sem consumo.

Além destes e de outros dados utilitaristas contra a tese utilitarista (resumidos em Petrinovich 2000:93-101), havia sobretudo a infinita complicação dos rituais sacrificiais e da maquinaria bélica que os alimentava, que 
ultrapassavam em muito qualquer benefício: não por acaso Bataille (1967) tinha feito do império asteca o paradigma da sua teoria sobre o consumo como núcleo da economia. Uma razão prática - como alegou na ocasião Marshall Sahlins - era insuficiente para dar conta de um sistema cuja chave deveria ser encontrada nos termos da própria cultura. O paradigma ecológico era vigoroso no momento e, à margem das simplificações do materialismo cultural, encontrou sua expressão em outras abordagens que poderiam ser rotuladas de etnoecológicas, como a de Duverger (1986), que interpretou o sacrifício asteca como uma tecnologia desenhada para se apropriar da energia e controlá-la num mundo ameaçado pela entropia.

Mas a polêmica deveria chegar muito mais longe, numa direção oposta. O artigo de Harner foi o principal catalisador de um livro de enorme sucesso, The man-eating myth, de William Arens (1979), que denunciava o canibalismo como uma obsessão fantasiosa de colonizadores e antropólogos. O livro de Arens cumpriu uma missão muito digna: encerrou uma época em que o canibalismo era um dado positivo, pronto para integrar os Human Relations Area Files, e mostrou que na imensa maioria dos casos as informações a seu respeito eram escassamente confiáveis: testemunhas indiretas, acusações estratégicas, mitologias tradicionais ou histórias de caçador. Mas Arens perdeu-se afinal por perseguir com demasiado ardor uma ala do inimigo derrotada com facilidade. Uma vez descartada a realidade factual do canibalismo, nas suas páginas não sobrava dele mais que uma dessas perversões do Ocidente que se projetam sobre nativos tão inocentes como inoperantes. O modo sumaríssimo com que Arens despacha testemunhos como o de Léry e Staden sobre o canibalismo tupinambá - ou mais ainda as fontes sobre o canibalismo asteca - mostra que estava demasiado ávido por se livrar da factibilidade canibal e que, em suma, talvez os canibalistas tivessem sido atacados por um adversário igualmente imprudente.

Contabilizar e comentar a literatura que desde então abordou o debate canibal seria uma tarefa interminável; ${ }^{2}$ apenas aludirei aqui a duas amostras que estabelecem tópicos importantes para esta discussão. Uma, o trabalho de Lestringant (1994), que se ocupa de detalhar e positivar um amplo setor do discurso canibal do Ocidente - sem exigir para isso que o canibalismo tenha sido apenas discurso ocidental. Lestringant mostra que, em meio às exotizações e demonizações, não faltou ao menos um momento de simpatia pelo canibal - o ensaio de Montaigne seria o seu ponto alto - quando a devoração do corpo do inimigo abatido foi vista como expressão de um ethos de vingança afim com o da aristocracia europeia. Essa simpatia pelo nobre selvagem foi dando lugar, nos três séculos seguintes, a uma visão utilitarista e miserabilista do canibalismo como recurso alimentar de populações pri- 
mitivas. Um canibalismo de necessidade, coerente com os grandes relatos que culminaram no século XIX: a evolução, a penúria econômica e moral dos seus estágios primitivos e a racionalidade do homo oeconomicus.

A outra contribuição - mais recente e a que dedicaremos maior atenção é a de Obeyesekere (2005), envolvida na costumeira polêmica com Marshall Sahlins (2003). ${ }^{3}$ O argumento de Obeyesekere continua e completa o de Arens, focando os dados polinésios: os astecas fazem uma aparição episódica, e o canibalismo tupinambá, embora ganhe um lugar paradigmático e gráfico - na capa e nas primeiras páginas, não é analisado, devido a uma declarada desconfiança do autor quanto à sua recepção no meio antropológico brasileiro. Trata-se, em suma, de reafirmar o canibalismo como uma variante do orientalismo: o que os relatos sobre o canibalismo revelam é, segundo Obeyesekere, um cannibal talk, um complexo folclórico europeu que viaja nos navios dos exploradores e se enriquece com fartas contribuições dos marujos; que define as expectativas dos colonizadores a respeito dos nativos e que eventualmente acaba por levar estes mesmos nativos a enfim encarnarem o estereótipo do devorador feroz, que já mais nada tem de nativo, em guerras coloniais.

O canibalismo é uma fábula europeia ou, no limite, uma realidade eurogênica. Obeyesekere faz uma ressalva, que aparecia também fugazmente em Arens: não nega que o consumo de carne humana tenha existido como prática vinculada ao complexo sacrificial maori ou fidjiano. Mas esta antropofagia divergiria radicalmente do canibalismo, sendo a primeira um ato religioso e frugal, e o segundo um festim bulímico, celebrado pela imaginação europeia, que em parte se confunde com o canibalismo de necessidade de Lestringant e em parte com a fome insaciável dos ogres e dos vampiros das fábulas. Não resumirei ou recriarei aqui os contra-argumentos de Sahlins, bem análogos aos que constam da anterior polêmica a respeito da divindade de Cook, e que discordam de Obeyesekere tanto na avaliação das fontes quanto nas suas implicações para um estudo do pensamento dos outros.

Prefiro centrar-me na distinção que Obeyesekere faz entre antropofagia e canibalismo, que parece constituir um esforço para distanciar o simbólico do real e do sensível. Os nativos de Obeyesekere parecem ora empertigados ritualistas que comem sem apetite, ora pós-modernos blasés, prontos para parodiar as obsessões europeias, nem que para isso tenham que se declarar canibais ou até tragar um filé humano oferecido pelos europeus num infame teste científico. Se os arautos do "canibalismo de necessidade" imaginaram uma devoração absolutamente profana, Obeyesekere parece propor uma antropofagia exclusivamente sacramental ou retórica. ${ }^{4}$ É a respeito desta distinção que um reexame do corpus sobre o complexo sacrificial-canibal mexicano pode ser útil. 


\section{Antropofagia e canibalismo no México}

A principal fonte a respeito do canibalismo asteca - e de virtualmente qualquer outro assunto do mundo mexicano - é a obra de Fray Bernardino de Sahagún, conhecida como Códice Florentino ou, na edição da parte em espanhol do seu texto, como História geral de las cosas de Nueva Espana (Sahagún 1995). O prestígio de Sahagún não é alheio aos seus objetivos, lato sensu inquisitoriais. Era um controle filológico da alma indígena o que ele pretendia com seus métodos e sua exaustividade, que já lhe valeram o reconhecimento de "precursor" da etnografia.

Auxiliado por nativos treinados no uso do espanhol e do latim e capazes de escrever em língua nahuatl com caracteres latinos, conduziu extensas pesquisas com informantes de várias cidades mexicanas, escolhidos entre os velhos mais versados na tradição e na leitura dos velhos hieroglíficos, produzindo um corpus de textos em náhuatl que mais tarde foram traduzidos pela equipe. ${ }^{5}$ Nesse corpus, a antropofagia nunca é tematizada ou consta das epígrafes. As referências a ela aparecem essencialmente nas descrições das festas dos deuses que compõem o livro 2, e com mais detalhes em uma das suas ocorrências no capítulo do livro 9 que trata da organização e dos costumes dos comerciantes. Essas referências não são especialmente sensacionais. Vejamos, por exemplo, a que aparece por motivo da festa de Tepeilhuitl (Sahagún 1995, capítulo XIII:936), na qual são sacrificados quatro mulheres e um homem, personificando figuras divinas: "chegadas abaixo, cortavam-lhes as cabeças e espetavam-nas num pau, e os corpos eram levados às casas que chamam de calpul, onde os repartiam para comer". Outras referências são igualmente sucintas: "E depois repartiam o corpo todo entre eles: comiam-no" (Sahagún 1995:96); "Depois de mortos, os coziam e os comiam" (ibidem XX:104). E assim por diante. Em outros casos, especifica-se um destino diferente dos corpos, totalmente incinerados ou jogados num sumidouro da lagoa mexicana. Maiores detalhes sobre o consumo são oferecidos por ocasião da descrição de um festival particular, o Tlacaxipehualiztli, sobre o qual voltaremos mais tarde:

Depois de esfolados, os velhos, chamados cuacuacuilti, levavam os corpos ao calpulli, onde o dono do cativo tinha feito seu voto ou promessa. Lá o dividiam e enviavam uma coxa a Montecuzoma para que comesse, e o resto o repartiam entre os outros principais ou parentes. Iam comê-lo na casa daquele que cativou o morto. Coziam aquela carne com milho e davam a cada um, um pedaço daquela carne numa tijela ou cuia, com seu caldo e seu milho cozido, e chamavam aquela comida de tlacatlaolli. Depois de terem comido, seguia-se a bebedeira (ibidem XXI:108). 
Esse consumo observa, no entanto, uma restrição importante:

O senhor do cativo não comia a carne porque fazia de conta que aquela era sua própria carne, porque desde o momento em que o tomou como cativo, o tinha como um filho, e o cativo ao seu senhor como um pai e, por esta razão, não queria comer daquela carne. Porém, comia a carne dos outros cativos que tinham sido mortos (ibidem XXI:110).

Uma descrição detalhada da antropofagia é feita igualmente no decorrer da festa de Panquetzaliztli, realizada pelo grêmio dos mercadores de escravos comprados para este fim. O Panquetzaliztli é um festival muito complexo, mas como de praxe o festim canibal em si é despachado rapidamente; há porém alguns detalhes importantes quanto ao consumo: "Da carne, colocada sobre o milho, comiam muito pouco. Nenhum chilli se misturava à cozinha ou à carne. Somente sal (ibidem, livro 9, XIV:575).

Sahagún não é um fabulador nem um propagandista, e na sua obra não demonstra grandes assombros em relação ao canibalismo. Junto com vigorosas alegações de simpatia pelos nativos e de reconhecimento de suas qualidades intelectuais e morais, permite-se de vez em quando sermões eloquentes sobre a sua depravação. Mas vejamos, por exemplo, o que diz do sacrifício e do consumo de crianças no festival de Atlcaualo:

É coisa lamentável e horrível ver que nossa humana natureza tenha chegado a tamanha baixaria e opróbrio, que os pais, por sugestão do Demônio, matem e comam seus filhos, sem pensar que nisto haja qualquer ofensa, antes pensando que com isto prestam grande serviço a seus deuses. A culpa desta tão cruel cegueira... não se deve imputar tanto à crueldade dos pais — os quais, derramando muitas lágrimas e com grande dor em seus corações a exerciam — quanto ao crudelíssimo ódio de nosso antiquíssimo inimigo Satanás que, com maligníssima astúcia, os persuadiu a tão infernal façanha (Sahún 1995 XX:107).

As diatribes contra os horrores da idolatria encontram-se em todos os autores da época, incluindo por certo os autores indígenas que, por sua vez, elaboram uma substancial historiografia nativa em nahuatl e em espanhol. Os conquistadores, naturalmente, as proferiam para defender sua empresa e seu botim — dos ataques desferidos por adversários temíveis, como o Padre Las Casas, e os missionários para justificar a sua missão. Os índios, diz mais tarde o Padre Acosta (2002, XXII:344), estavam cansados de sua religião e desejosos de adotar outra mais "agradável". O sistema sacrificial não decorre da barbárie dos mexicanos, mas das astúcias do diabo e do engano dos sico- 
fantes, que propiciavam os sacrifícios alegando a fome dos deuses (Acosta 2002 XXI:343). O cannibal talk mexicano era vasto, complexo e matizado, e não servia para construir um indígena monstruoso. Nem sequer era bem um cannibal talk, já que dificilmente se encontram referências a ele que prescindam do seu contexto religioso.

O principal estigma esgrimido contra os astecas - ou mais exatamente contra os seus sicofantes - é o de sacrificadores, não o de canibais, que segue o primeiro apenas como uma sombra. E precisamente como matéria religiosa ele deveria ser erradicado com todo o sistema da idolatria a que servia de chave. Na escassa medida em que podia ser segregado da idolatria, o canibalismo era encarado pelos espanhóis como uma atitude, digamos, moderna, nos termos de Lestringant: o protomédico Hernández, por volta de 1577 (2000:145), atribuía a sua aparição à grande fome que tinha acontecido cem anos antes. O mesmo Hernández (:122) diferencia, bem ao estilo de Obeyesekere, uma prática dos reis, "que não comiam por nada carne humana, salvo, por motivos religiosos, a dos imolados aos deuses", da prática de todos os outros, que "a comiam com prazer, sempre que fosse do inimigo ou dos matados em guerra". Provavelmente Hernández está dando voz a um amálgama entre preconceitos hierárquicos astecas e espanhóis: nenhum cronista, nem ele mesmo, deixa espaço para um tratamento não-religioso do inimigo, e sua informação pode ser melhor entendida como um juízo sobre diferentes éticas de consumo aplicadas a uma mesma prática. ${ }^{7}$

Mas não descartemos por isso o peso do estigma canibal na cena mesoamericana. Ele poderia explicar, talvez, a diferença de tratamento que o tema merece da parte de uma série de cronistas que o abordaram no século XVI e em começos do século XVII. Barry L. Isaac (2005), que cuidou de fazer essa comparação, identifica atitudes diferentes em três tipos de cronistas: os espanhóis, os indígenas e os mestiços. Os espanhóis são conquistadores ou missionários; os indígenas são membros da aristocracia nahuatl que ocupavam ainda nessa época um lugar de importância no regime colonial, antes de serem reduzidos, no século a seguir, a uma mínima expressão, à dissolução ou à integração nas elites criollas ou espanholas. Os mestiços ficam entre uns e outros, mais perto dos últimos que dos primeiros. O resultado da comparação não tem a princípio nada de surpreendente: as afirmações mais enfáticas do canibalismo encontram-se nas obras dos espanhóis, enquanto o tema é tratado com reservas ou está totalmente ausente nos escritos dos indígenas. Os relatos mestiços - como o de Pomar, mais tarde citado - oferecem um meio-termo entre os anteriores, uma afirmação matizada. O que significa essa diferença? Ou, em outras palavras, quando os autores indígenas deixam de falar do canibalismo eles estão elidindo 
um tema molesto ou simplesmente, e por razões óbvias, estão descartando o falso bordão de uma propaganda hostil? Há várias razões para se supor que seja o primeiro. Vejamos, por exemplo, Tezozómoc (2001), ${ }^{8}$ um autor que em momento algum alude ao consumo efetivo de carne humana pelos seus ancestrais, e que numa ocasião (ibidem, cap.55:237) glosa como "comida de gente buena" - comida legítima, poderíamos dizer - o tipo de tortilla, tlacatlacualli ou tlacatlaolli, que Sahagún descreve como tortilla com carne humana: afinal, "sustento humano" é um termo suficientemente ambíguo para permitir ambas as interpretações, sem refutar uma ou outra.

Tezozómoc mostra-se coerente em relação a Sahagún quando este descreve um destino dos corpos diferente do repasto canibal; nos casos em que Sahagún explicita que as vítimas do sacrifício são comidas, Tezozómoc perde todo o interesse pelo destino dos corpos. Isto nos leva a uma evidência negativa que deveria ser levada em consideração em qualquer desconstrução do canibalismo asteca: os autores que com maior autoridade e interesse poderiam tê-lo negado, isto é, os sucessores diretos da nobreza asteca, não negaram o canibalismo, embora o elidissem. Ou, de outro lado, o elidiram, embora não o negassem. Eles trovejam contra a idolatria e os sacrifícios com a mesma ênfase que os espanhóis usam, mas não incluem a antropofagia nessa lista de pecados. Suas crônicas são monumentos à glória da nação asteca, mas eles não se ocupam em limpar essa glória da calúnia do canibalismo - o que não lhes estaria vedado: o canibalismo indígena não era artigo de fé.

De fato, os autores indígenas e os mestiços empreenderam tarefas ousadas na apologética do seu passado. Fernando de Alva Ixtlilxóchitl (2000), por exemplo, desenvolve um argumento extenso e coerente para desculpar a cidade de Texcoco pelo estigma do sacrifício humano. Este aparece nas suas páginas como um costume imposto pelos tenochcas, que Nezahualcóyotl, o modelo de rei texcocano, esforçou-se em moderar (ibidem XLI:168). O mesmo Nezahualcóyotl é por ele apresentado como um rei filósofo que, desenganado em face da vaidade dos ídolos, elabora um culto a um Deus desconhecido (ibidem XLV:181). O complexo de Quetzalcoatl — o rei-deus oposto ao sacrifício humano, expulso pelo sombrio e violento Tezcatlipoca pode ser, como querem os etnólogos (por exemplo, Duverger) testemunho de uma religião pré-asteca mais benévola, mas é claro que chegou a nós reelaborado por uma elite local criolla que ensaiava com ele uma aproximação entre o universo religioso nativo e o cristianismo (Lafaye 1977:205-291).

Tais argumentos foram bem recebidos pela ideologia colonial, se é que não foram os seus produtos mais ilustres. À diferença do que acontece na costa brasileira ou nas ilhas Fidji, os conquistadores não pretendiam retratar 
os seus dominados como selvagens sem fé, lei nem rei, ou dominados por uma miséria que leva a comer, digamos, do próprio corpo; seria difícil em vista do esplendor das suas cidades, que já era motivo de glória para os invasores. Mas a negação do canibalismo teve que esperar a chegada de Arens.

Para aprofundar as razões que determinavam essa atitude duplamente reticente dos autores indígenas, precisaríamos nos deter em algo que a literatura pós-colonial parece sempre pouco disposta a frequentar: a opacidade do próprio discurso indígena. Este objetivo é difícil e para levá-lo longe o suficiente requereria sem dúvida conhecimentos mais densos do que os que eu possuo. O que se seguirá é, portanto, um ensaio provisório, que pretende reler textos bem conhecidos, e também tirar algum proveito da aproximação entre os dados sobre o canibalismo asteca e os que nos oferecem as Terras Baixas da América do Sul, dos Tupinambá históricos aos Wari contemporâneos.

\section{A diversidade canibal}

Talvez um bom começo seja o próprio Tezozómoc, um autor raramente citado nos escritos sobre o canibalismo asteca pela simples razão de que jamais faz alusão a ele, isto é, jamais alude a um consumo factual e voluntário de carne humana pelos seus ancestrais, o que pode ser uma acepção excessivamente reducionista do canibalismo. Se ampliarmos esta acepção, então Tezozómoc pode ser uma fonte de primeira ordem: não tanto pela quantidade, mas pela diversidade dos elementos que traz à tona; não tanto pela originalidade (todas as suas informações podem ser encontradas, às vezes com maior detalhe, em outros cronistas), mas pela organização do conjunto que uma obra extensa como a dele possibilita.

Em sua Crônica Mexicana, Tezozómoc refere-se ao canibalismo em diversas ocasiões. Em primeiro lugar, como um apanágio da bruxaria. Assim, no capítulo 1 (Tezozómoc 2001:56), em que trata das migrações originárias dos astecas, descreve assim a bruxaria de Malinalxoch, uma deusa que migra com os astecas: "Olhando uma pessoa, no outro dia, morria: lhe comia vivo o coração e, sem sentir, a olhá-lo, lhe comia a barriga da perna". Esse olhar canibal é doravante a potência própria dos feiticeiros: teyolocuani e teixcuepani são especialistas em devorar o coração ou a barriga da perna. E têm ainda o poder de alterar a visão de suas vítimas: em lugar de um bosque ou um rio, vêm grandes animais ou algum ser horrível — essa indução a alucinações é a especialidade de mais um tipo de bruxo, o tecotzana. Quando, numa era muito mais tardia (Tezozómoc 2001:112,482-3), Moctezuma envia 
feiticeiros dessas mesmas categorias contra os espanhóis feiticeiros, eles fracassam porque não encontram nos seus adversários corações ou corpos adequados à sua ação.

O canibalismo de Malinalxoch sintetiza a agressão xamânica, aliás, uma prática infame, que leva os astecas a abandonarem a feiticeira. Mas eis aqui que práticas muito semelhantes e formuladas em termos bem mais materiais são atribuídas àquele que, irmão de Malinalxoch, será considerado o deus étnico dos astecas:

No próprio lugar de Tlachco [é o lugar do jogo de bola], no buraco da água que está no meio, Huitzilopochtli tomou Coyolxauh e a matou, degolou e lhe tirou o coração. E amanhecido outro dia, bem cedo, os Tzentonapas mexicanos viram todos os corpos esburacados, nenhum deles tinha coração; outros foram comidos por Huitzilopochtli, que se tornou grande bruxo (Tezozómoc 2001:60).

A carne humana é o alimento dos deuses. No capítulo 109 (:471), Moctezuma obsequia Cortés, cuja identidade ele quer esclarecer, com vários presentes de alimento, incluído um escravo para ser comido: "E se quisesse carne humana e os comesse, seria em muito boa hora". Tezozómoc não explicita o que essa preferência indicaria, mas a anedota, contada por praticamente todos os cronistas e citada pelo próprio Montaigne no final do seu ensaio "Sobre a moderação", tinha uma chave bem conhecida: a opção pela carne humana caracterizaria os espanhóis como um tipo de deuses. Alimentar os deuses era, como reza uma interpretação bem conhecida, o motivo da guerra sacrificial asteca: "Já, enfim, com essas mortes, dá de comer ao vosso deus e senhor, o tetzahuitl, ar, crendice Huitzilopochtli"(cap. 54:234), sem, aliás, fazer diferença entre a carne de amigos ou inimigos: "o sol comia de ambos os exércitos" (cap. 102:438).

A noção de um cosmos predador que deve ser alimentado com vítimas humanas, central em explicações como a de Duverger, já era um ideologema muito consciente para os astecas e, em particular, para Tezozómoc, cuja crônica é uma enumeração das guerras de conquista dos astecas. Sacrifícios menores, em que a língua, o sexo ou outras partes do corpo eram perfurados com espinhos de maguey ou cortados com lâminas de obsidiana para fazer destilar o sangue na terra, faziam parte do cotidiano dos sacerdotes e se incluíam em praticamente todos os rituais - autoimolação que de resto reproduzia aquele que os próprios deuses deviam pôr em prática para a criação e a manutenção do mundo.

A apoteose desse autossacrifício seria xochiyaoyotl, a guerra florida, ou glosando o termo, o jogo bélico, um afrontamento entre México (e seus aliados) 
e as cidades inimigas que tinham ficado ilhadas em meio à expansão imperial mexicana. A guerra "civil e florida" (Tezozómoc 2001:412) é apresentada pelos ideólogos astecas como uma batalha acordada entre as partes, sem mais intenção do que conseguir de um lado e outro cativos para o sacrifício, quando as fronteiras de expansão imperial já estavam longe demais. Ixtlilxóchitl (2000:169) especifica que essa fonte de alimento seria mais grata aos deuses: "pois como sua iguaria, seria quente e recente, tirando-as [as vítimas] deste campo". O banquete é simétrico, e o canibalismo divino é acompanhado do sacrifício dos deuses devorados pelos homens. Essa teofagia acontecia pelo menos de dois modos: em primeiro lugar, pelo sacrifício e consumo de vítimas humanas que personificavam deuses, do qual já demos um exemplo tirado de Sahagún: a carne desses sacrificados era um repasto exclusivo para os membros da elite asteca. Mas acontecia também pela elaboração de uma imagem de Huitzilopochtli, feita de pasta de amaranto, que era sacrificada, indo seu coração para o rei, e o resto comido por todos (Sahagún 1995:204).

Toda essa sacralização do gasto humano (ou divino) não impede que o canibalismo seja ao mesmo tempo uma ideia non sancta, apropriada para as ameaças e as ofensas que organizam a reciprocidade negativa entre as cidades mesoamericanas. Assim, no prelúdio, há mais uma expedição vitoriosa dos mexicanos; estes recebem as injúrias dos chalcas: "Vinde logo, mexicanos! Cheguem logo, que nossas mulheres estão esperando vossos corpos para guisá-los em chili" (cap. 25:122).

As crônicas recolhem com frequência esse tipo de ameaça guerreira. Assim o faz Bernal Diaz, narrando os primeiros encontros com os tlaxcaltecas; assim, falando do assédio de Tenochtitlan, o faz López de Gómara, que também alude ao mole com que a carne seria preparada. Reparemos neste detalhe culinário ao qual não se tem dado a devida atenção. Os informes de Sahagun são explicitamente contrários a este detalhe: a carne humana do sacrifício não podia ser preparada com chili, mas somente com milho cozido, o sal como único tempero, e é evidente que tal limitação a separava decisivamente da comida normal. ${ }^{9}$ A diferença entre um repasto sagrado, e provavelmente real, e outro nefando, e provavelmente retórico, inclui a separação entre uma cozinha sagrada e uma cozinha profana e, note-se bem, feminina. É apenas esta última que é esgrimida nas bravatas e nas ofensas que se trocam entre inimigos. Veja-se o que acontece quando as mulheres de Xochimilco preparam para os seus governantes um caldo com peixes, rãs, patos e outras iguarias que tinham comprado das mulheres astecas: "começando a comê-lo, estava muito saboroso e prosseguindo a ingestão, logo acharam nas panelas cabeças como as de crianças e mãos e pés de pessoas, e tripas" (cap.18:100). 
Essa comida horrenda, uma provocação que obviamente dá lugar a mais uma guerra, traz de novo à tona a face nefanda do canibalismo, caracterizada aqui pela sua confusão com o repasto cotidiano em função da sua agência feminina e, ainda, pela capacidade de transformação — ou de ilusão, já notada a respeito de Malinalxoch — o que permitiu às mulheres astecas venderem a carne humana como carne animal. O canibalismo sagrado, como podemos ver, era um assunto masculino, e bastava a mediação feminina - ou, em outros termos, a culinária profana — para transformá-lo em abominação. Um outro episódio narrado por Tezozómoc, a guerra entre México e Tlatelolco - cidades gêmeas densamente ligadas por laços de aliança - incrementa o panorama de mulheres fatais de Xochimilco: não há aqui referências a canibalismo, mas sim às ações femininas como desencadeadoras da guerra, e uma estranha conclusão em que as mulheres tlatelolcas, invertendo o episódio anterior, se vêm tratadas como patos. ${ }^{10}$

Essa mesma guerra de Tlatelolco serve também para explicitar um outro sentido do canibalismo. Ao lado da obscenidade das mulheres de Tlatelolco (cf. nota anterior), outra ofensa tinha precipitado o conflito, quando os homens da cidade tinham apostrofado assim os seus aliados: "Vindes a vender algo ou vindes a vender vossas cabeças ou tripas ou corpos?" (cap. 44:194). É precisamente esse comércio o serviço que os tlatelolcanos — fazendo a oferta de tributo que servia de praxe para selar a submissão após a conquista oferecem aos mexicanos vencedores: "E lá vamos ao comércio humano, a vender nossas cabeças, peitos, braços, pernas e tripas e, com isso, vimos às mãos e às armas e nelas achamos riquezas, plumária riquísima, ouro, pedras preciosas" (cap. 48:210).

A crônica de Tezozómoc é pródiga em informações sobre o papel dos pochtecas ou mercadores (uma classe muito identificada com Tlatelolco e em evidente ascensão no panorama sacro-militar do império asteca) na expansão territorial mexicana. Misto de comerciantes, espiões, desbravadores e soldados, eles constituem também uma espécie de diplomacia negativa, servindo como pretexto para boa parte das guerras, sobretudo quando elas são travadas mais distante. Mas essa noção do próprio corpo, constituindo, por assim dizer, o capital inicial das suas incursões comerciais, sugere de fato uma outra ideologia do canibalismo, ao mesmo tempo auxiliar e concorrente da teoria "cósmica": o corpo humano pode ser o preço da relação entre homens e divindades, mas é também o veículo de uma troca comercial que, contrariando o paradigma clássico, não é bem uma alternativa à guerra, mas o seu outro nome. ${ }^{11}$

A carne humana é moeda num sistema de trocas que não se restringe à atividade dos pochteca, comerciantes de longa distância. Propriedade 
daquele que capturou um inimigo, ela não se destina ao consumo doméstico: entra num sistema de dádivas que percorre, preferente ou exclusivamente em sentido vertical, a sociedade mexicana. Sabemos que Tezozómoc não se refere nunca ao consumo efetivo de carne humana, e a citação aqui é de Pomar, um autor mestiço:

Os corpos, depois que seus donos os levavam, eram feitos em pedaços, e cozidos em grandes panelas; eram enviados por toda a cidade e por todas as vilas da região, até que não sobrasse coisa nenhuma, em pedaços muito pequenos cada um não tinha nem meia onça - como presente aos caciques, senhores, principais e mordomos, e a mercadores, e a todo gênero de homens ricos dos quais entendiam que obteriam algum lucro, sem que se averiguasse que para si próprios deixassem coisa nenhuma [do corpo] para comer, porque lhes era proibido, salvo os ossos, que guardavam como troféu e sinal do seu esforço e valentia, pondo-os em sua casa num lugar em que quem entrasse pudesse ver. Aqueles a quem presenteavam com um pedacinho desta carne davam-lhes cobertores, camisas, anáguas, plumas ricas, pedras preciosas, escravos, milho, batoques e brincos de ouro, rodelas, vestidos e arreios de guerra, cada um como queria ou podia, não tanto porque tivesse aquela carne algum valor pois muitos não a comiam - mas sobretudo como um prêmio ao valente que a enviava, com o que ficava rico e próspero (Pomar 1582).

Mesmo dentro do grupo, podemos ver que o dom da carne humana é um dom ambíguo e agressivo que se aceita de modo reticente, ${ }^{12}$ e que administra a hierarquia social: carne humana em troca de riqueza e prestígio. Mais um fragmento de Tezozómoc põe essa mesma troca no centro do contrato social asteca. No debate sobre a conveniência ou não de fazer guerra contra os tepanecas, então senhores dos astecas, o partido da paz e da submissão propõe um trato aos porta-vozes do partido da guerra. Se forem derrotados, sofrerão uma morte cruel: "e depois de mortos, iremos comer vossas carnes, porque quando viemos e saímos de nossas terras, não trouxemos familiares nem parentes, senão muito diferentes uns dos outros" (cap. 9:74-75).

Se, pelo contrário, a insurreição for triunfante, comprometem-se a servir os guerreiros e a dar-lhes suas filhas em casamento. Será, em suma, o início da hierarquia entre os pipiltin (nobres) e os macehualtin (homens comuns), mas também o início do vínculo social entre esses membra dissiecta que acabaram constituindo o povo asteca. A diferença entre os grupos que doravante constituirão a força asteca permite tanto a devoração dos corpos quanto a aliança matrimonial. A carne dos nobres é o penhor que, depois do triunfo dos insurgentes, dará lugar ao estabelecimento de 
relações carnais de outro tipo. Chegado a este ponto, o canibalismo, real ou virtual, está bastante longe das elaborações cosmológicas que sempre - a partir das próprias interpretações indígenas - têm sido associadas a ele. A devoração não se estabelece apenas num grande eixo vertical que une, através de um altar no topo da pirâmide, o mundo dos humanos e o dos deuses. Ela diz respeito também à sociabilidade terrena, como no caso dos Tupinambá. ${ }^{13} \mathrm{~A}$ captura, o manejo e a imolação do cativo criam e sustentam redes de troca no interior da cidade, e as estendem integrando as vítimas na rede de parentesco dos seus captores. ${ }^{14}$ Mesmo deslocada do ápice do sacrifício - não há, como no caso tupinambá, uma enunciação das mortes passadas e futuras no momento do abate - a vingança é também no caso asteca o motor da guerra sacrificial, que deve se manter como elo entre os inimigos, mesmo contrariando iniciativas mais diplomáticas (Tezozómoc 2001, cap. 26:124-126).

As diferenças por certo são igualmente evidentes. Se o caso tupinambá se caracteriza pela sua horizontalidade - uma vítima equivale à anterior e à próxima sem que nenhuma relação prevaleça sobre a que existe entre inimigos — os astecas privilegiam a dimensão vertical. A aliança evocada por Tezozomoc - já por si só situada num discreto segundo plano atrás da colaboração com os deuses - é a que acontece entre aristocratas e gente comum; a relação entre cativo e captor é de filiação, e não de afinidade, como no caso tupinambá, e a sexualidade às vezes exercida pela vítima é uma hierogamia, e não uma aliança terrena; a pirâmide mexicana substitui a praça tupinambá.

\section{O canibalismo como processo civilizatório}

Outros dados podem ampliar ainda mais a pertinência desta comparação, avançando num terreno muito bem conhecido dos amazonistas. O sacrifício asteca é identificado frequentemente com a predação entre espécies. Além dessas estranhas histórias de patos e peixes mutantes que já resenhamos na obra de Tezozómoc, aponta nesse sentido o festival de Quecholli (Sahagún 1995, cap. XIV:94), em que os habitantes de México e Tlatelolco realizam uma grande caçada coletiva nos bosques de Zacatépec. Na descrição de Sahagún, essa festividade tem certo sabor de piquenique, de volta às origens caçadoras de uma população já marcadamente urbana.

Acabada a caça de veados e coelhos, cujas cabeças são carregadas como troféus, tem lugar uma matança de escravos no templo de Tlamatzinco. Nessa ocasião, as vítimas - que nos outros casos subiam até o altar pelos 
próprios pés - são carregadas degraus acima atadas de pés e mãos, como animais levados ao abate. De fato, não faltam complementarmente as referências textuais e iconográficas ao sacrifício de animais realizado segundo os padrões do sacrifício humano, isto é, no altar sacrificial e por extração do coração. Como lembra Duverger (1986:192) ao comentar estes dados, as duas palavras usadas para designar os cativos sacrificados - mamatlin e tlaalxiltin - serviam igualmente para designar as peças de caça.

Mas o dado mais expressivo deste conjunto é o festival do Tlacaxipehualiztli, uma variante de sacrifício que sistematicamente ocupa o primeiro plano da atenção de todos os cronistas, até o ponto de aparecer como o rito sacrificial por excelência. O Tlacaxipehualiztli é a ocasião em que os dignitários das cidades inimigas são convidados a presenciar a cerimônia em que seus próprios compatriotas são sacrificados; é também a ocasião em que os informes de Sahagún introduzem maiores detalhes sobre o consumo de carne humana e, em particular, sobre a evitação deste consumo por parte do dono do cativo. As suas vítimas são guerreiros escolhidos entre os cativos: um a um, atados pelo pé a uma enorme pedra circular, e precariamente armados, eles enfrentam guerreiros-águia e guerreiros-jaguar, em geral em número de quatro, ${ }^{15}$ até desfalecerem e serem levados até a pedra dos sacrifícios para serem submetidos à execução de praxe.

Os guerreiros-águia e os guerreiros-jaguar eram combatentes de elite que envergavam máscaras, ou a rigor peles com as cabeças desses predadores, símbolos centrais do acervo asteca que, na teoria da devoração cósmica, personificavam obviamente o sol predador. Mas é igualmente possível, e talvez mais simples, observar que, representados por esses guerreiros revestidos de roupas de predador, os astecas relacionavam-se com as suas vítimas enquanto águias e jaguares. A equação é mais evidente se, seguindo Graulich (1982:223), repararmos na representação anômala que o códice Nuttall faz daquilo que os espanhóis chamaram de sacrifício gladiatório: os jaguares aparecem tendo como únicas armas as garras dos predadores com cujo corpo estão revestidos. Isto explicaria o termo tlahuahuanaliztli, "raiamento" com que era conhecido o episódio.

Todos os sacrifícios astecas contavam com um longo ritual prévio à imolação propriamente dita, mas o Tlacaxipehualiztli é provavelmente o único caso em que a imolação - executada quase sempre pela extração do coração - deixa de ser o foco da cerimônia para se transformar num epílogo. Ou, a rigor, numa transição, porque ela é seguida por um episódio ulterior igualmente marcante que dá nome ao festival. O corpo dos sacrificados é esfolado, e sua pele é revestida pelos astecas. Os escolhidos para essa função podem ser muitos: os próprios guerreiros que antes se revestiam de 
peles de predadores, o dono do cativo, algum homem que sofra de doenças cutâneas, ou qualquer outro ao qual o dono da vítima conceda esse privilégio, ou essa carga, porque a pele deveria ser vestida ininterruptamente por vinte dias. Durante esse tempo, o portador recolhe esmolas que divide com o dono: uma requisição agressiva de dádivas que evoca aquela que, simultaneamente, segundo a anterior citação de Pomar, estaria acontecendo com a carne do sacrificado.

Os oficiantes revestidos da pele do sacrifício - tototecti - um termo que designa igualmente a vítima e o oficiante que envergava a sua pele (Sahagún 1995, XXI:107-108) — travam combates rituais contra grupos de guerreiros, os quais resultam por sua vez em capturas e resgates. O inimigo, revestido pelos seus matadores, exerce uma presença belicosa no próprio reduto destes.

Mais uma vez, o ritual remete a paralelos sul-americanos. O cativo amarrado, enfrentando os seus captores com armas precárias e comprometido com uma performance bravia, evoca decerto o cativo tupinambá. Mas, por outro lado, o duelo entre humanos é substituído por um duelo entre seres que trocam de roupa, contando-se entre essas "roupas" a pele dos predadores arquetípicos e, em lugar de destaque, a própria pele dos sacrificados. Sabemos que nas cosmologias das Terras Baixas sul-americanas essa outra pele vale por outro corpo, dotado de potências outras; daí, essa operação de revestimento equivale a uma transição entre naturezas diferentes (Viveiros de Castro 1998). O rito sacrificial asteca, classicamente interpretado como uma técnica de alimentação do cosmos e que acabamos de caracterizar também como um sistema de trocas que regula, real ou virtualmente, a rede de alianças comerciais, políticas e matrimoniais, aparece finalmente como um rito transformacional, no qual vigora a permutabilidade de deuses, homens e animais.

Se o homem pode se tornar deus revestindo as roupas e os atributos dos deuses - argumento central de boa parte dos sacrifícios relatados por Sahagún - pode também se tornar jaguar revestindo a pele e as garras do jaguar; do modo mais literal possível, pode inclusive virar inimigo entrando na própria pele do inimigo. É esta capacidade de devir outro que, em trabalhos bem conhecidos, primeiro sobre o canibalismo, depois sobre o perspectivismo ameríndio (Viveiros de Castro 1986, 1992, 1998), tem sido identificada como a base de uma epistemologia das terras baixas americanas, isto é, dos selvagens. Num universo animista ou perspectivista constituído essencialmente de sujeitos, onde homens, deuses e animais se equiparam pela capacidade comum de exercer um ponto de vista, as diferenças estão depositadas nos corpos, e podem ser superadas mediante uma troca de corpo, 
de roupa ou de pele, realizada nas visões do xamã ou em rituais como o Tlacaxipehualiztli. Os astecas, é claro, não se percebiam como selvagens; mas sim em contraste com selvagens. É o mesmo conflito íntimo que no mundo andino separa o universo geométrico e solar do Tahuantinsuyo das suas origens selvagens, encarnadas numa Amazônia monstruosa povoada de sucuris e jaguares (Renard Casevitz et alii 1986; Molinié 2001). A forma anômala do Tlacaxipehualiztli — combate ritual brevemente interrompido para dar lugar a um sacrifício canônico - ocupa a mesma margem que as crônicas astecas outorgam à prática xamânica; faz parte do acerto de contas do Império mexicano com umas origens bárbaras ambiguamente consideradas. Os astecas assumiam como próprio um pólo chichimeca, selvagem, em oposição a um outro pólo tolteca, responsável pela sua sedentarização e seu refinamento.

Ixtlilxóchitl (2000:74-77) dedica páginas expressivas — inclusive pelo seu teor fantasioso - à descrição de um Texcoco chichimeca e selvático, ainda não habituado à agricultura, em que a caça é oferecida em sacrifício no templo, e os bons modos da vida sedentária são introduzidos, à força se necessário for, pelo soberano. O pesado estigma que recai sobre a feitiçaria "canibal" - identificada no relato de Tezozómoc com a figura arcaica de Malinalxoch - é correlato da ereção de um sistema sacrificial de Estado que aspira ao monopólio do canibalismo ou, tout court, a um monopólio do poder simbólico, cujas brechas apenas aparecem cá e lá nas crônicas contemporâneas. ${ }^{16}$

O sistema sacrificial asteca, por assim dizer, não interpreta o mundo diretamente: ele é uma elaboração secundária de um complexo mais antigo, mais ou menos como a eucaristia cristã é uma elaboração secundária do sacrifício judaico. Ao mundo selvagem de olhares canibais e transformativos se opõe assim um outro, regulado pelos teólogos e os estadistas, presidido por um predador e um ponto de vista absolutos - esse sol que "come dos dois exércitos". Não é esta uma leitura induzida por um evolucionismo tardio. Hernández, um autor menos comprometido com o olhar da aristocracia asteca, já se refere a um conflito entre, de um lado, reis e teólogos e, de outro, o vulgo que multiplica os deuses sem permissão das elites e que "não só atribuía a divindade aos irracionais, mas também a objetos inanimados e carentes de sentido" (Hernández 2000:164).

O ritual asteca precisava dar conta de um conjunto de tradições, e não só da ordem do cosmos; é compilatório e sintético. Ele insere numa ordem periódica - lembremos que Sahagún descreve o seu universo sacrificial ao fio dos meses do calendário asteca — uma multidão heterogênea de relações entre os diversos protagonistas do cosmos, e as submete a uma forma ritual 
canônica. É fácil notar, nas descrições da religião mesoamericana, o excesso simbólico que desborda esse cânone, fomentando interpretações diversas de um ritual como o sacrifício gladiatório, identificado ora como ritual agrário, ora como intimidação política, e vinculado às mais diversas divindades. Longe das notícias mais ou menos fantásticas sobre um canibalismo xamânico ou guerreiro que as fontes prodigam, o consumo ritual de carne humana, tal como aparece nas informações mais confiáveis, parece um elemento regular e bem regrado dessa vulgata controlada pelos sacerdotes e a aristocracia um sacramento que fixa as possibilidades de transformação: um modo de domesticar uma cosmologia selvagem, não um resíduo desta.

\section{Interpretações, redes, comparações}

Cada uma das figuras do canibalismo aqui resenhadas exigiria sem dúvida uma maior definição, mas mesmo nesta primeira aproximação é forçoso reconhecer a sua diversidade. As fontes nos oferecem uma densa rede de objetos canibais (narrações, rituais, metáforas, monumentos) e de sujeitos que se relacionam através deles, acusando, explicando, negando, simbolizando, celebrando e eventualmente comendo. Entre esses objetos, há também múltiplas interpretações nativas - astecas ou espanholas - aquelas que, devemos reconhecer, pouco precisaram acrescentar às interpretações dos estudiosos posteriores. Primordial ou contemporâneo; real ou virtual; sacerdotal, profano ou xamânico; sociológico ou cosmológico; guerreiro ou comercial; teocêntrico ou perspectivista; aristocrático ou popular; virtuoso ou nefando, o canibalismo asteca está em toda parte. Permite vastas diferenças, compõe-se por igual de doutrina antropofágica e de doutrina anticanibal, e não se poderia falar verdadeiramente do velho México sem se referir a ele direta ou indiretamente.

Trata-se, em suma - lembrando do célebre idioma bovino de EvansPritchard - de um idioma canibal, algo muito mais vago, heterogêneo e resiliente do que uma sociedade, uma cultura ou uma religiáo canibal. Os debates sobre o canibalismo tentam, em geral, domar essa pluralidade e coagular essa fluidez. Todos os esforços se dirigem para esclarecer um canibalismo que clamaria por uma interpretação: os testemunhos contraditórios são, portanto, usados como argumentos ou contra-argumentos, não como segmentos de um conjunto. Os desconstrutores do canibalismo nos obrigam a escolher entre o canibalismo e o não-canibalismo, enquanto o dilema dos astecas - não menos sensíveis que nós ao horror - parece ter se estabelecido entre bons e maus modos de ingerir a carne humana. Quando esta 
alternativa existe, como na distinção de Obeyesekere entre antropofagia e canibalismo, é ao preço de desvinculá-las, fazendo-as incomunicáveis, como se a abominação da carne com chili pudesse sobreviver sem o sacramento da carne com milho.

O relato poderia seguir desde aqui dois caminhos que prolongariam excessivamente este artigo. Poderíamos nos perguntar como o canibalismo, outrora assimilado a outros signos da barbárie, como o sacrifício humano e a tortura, veio a ser destacado, por Arens ou Obeyesekere, como o horror que deveria ser refutado a favor da honra do nativo. Ou poderíamos voltar ao silêncio reticente da elite indígena mexicana sobre este detalhe de uma civilização que de resto eles advogaram e reinterpretaram com eloquência. Em ambos os casos, deveríamos empreender uma longa reflexão simétrica que não poderia deixar de lado a presença de imagens canibais bem no centro da cultura ocidental. Ficará para outra vez.

Por enquanto, nós nos limitaremos a retomar uma comparação em que pouco poderá ser feito além de recapitular similitudes já expostas. O idioma canibal em Mesoamérica apresenta uma gramática e um léxico muito familiares aos amazonistas. ${ }^{17}$ Isto não é dizer pouco; e é quase tudo o que pode ser dito, pois em contraste os idiomas da etnologia mesoamericana e da amazônica são praticamente incomensuráveis. Nunca houve no México, de Cortés em diante, dúvidas sobre a presença de verdadeiros Estados e verdadeiras religiões de fé, de lei e de rei. A etnologia mesoamericana cresceu apoiando-se sobre estes conceitos, e o próprio canibalismo foi entendido como um canibalismo de Estado, religioso ou alimentício, raramente comparado (a não ser como um resquício de barbárie genérica) ao dos selvagens.

O modo com que o México independente tem lidado com seu passado indígena depende desse reconhecimento temporão da sua dignidade estatal. Em contraste, como sabemos, a recuperação do selvagem pelo indianismo e pelo modernismo no Brasil foi à procura de uma diferença - contra o passado colonial ou contra o Estado. A etnologia amazônica-brasileira atual é uma positivação do que secularmente foi visto como deficiência (de Estado ou de religião, primeiro; de grupos corporados, mais tarde); desvenda o papel estrutural de coisas como a corporalidade, a plumária ou o próprio canibalismo. Mas a corporalidade, a plumária ou o canibalismo, malgrado a riqueza com que aparecem nas fontes mesoamericanas, estão longe de estruturar as descrições do mundo asteca, que são fundamentalmente arquitetônicas, históricas e teológicas. Qualquer comparação entre Mesoamérica e Amazônia sofre de um excesso de lacunas.

Mesmo assim, alguns pontos provisórios podem ser fixados. O ponto crítico de ambos os sistemas — talvez comum a outros canibalismos, se não 
a todos - está nas suas negações: quem não deve comer, como não deve ser comida a carne humana são detalhes mais eloquentes que as vagas alusões às virtudes positivas do seu consumo. A carne humana, por assim dizer, já está culturalmente digerida antes de ser naturalmente ingerida. O canibalismo, como o incesto, aparece em cena como proibição - mesmo nas culturas canibais, ou especialmente nelas - exercendo um enorme poder classificatório: numa cosmologia perspectivista são as limitações do consumo canibal, e não uma condição com atributos fixos, as que definem o humano, o divino, o animal, o escravo e o aristocrata. A prática canibal, como propõe Vilaça (2000:102), introduz assim diferenciações concretas contra as reduções simétricas que, na falta desses atributos fixos, encontrariam canibalismo em toda a parte (porque todo alimento possível é humano) ou em nenhuma (porque todo alimento pode ser desumanizado para o seu consumo).

Da Amazônia para o México muda o perfil de tais diferenciações. $O$ canibalismo amazônico organiza-se num eixo que vai do canibalismo bélico ao canibalismo funerário. Estes extremos foram uma vez identificados com a oposição entre exo e endo-canibalismo: o consumo do inimigo é como o consumo de carne de caça; o do parente defunto, um sacramento que almeja libertar sua alma, ou prevenir o seu consumo por inimigos. Os prefixos exo e endo supõem uma distinção diametral há muito posta em dúvida (LéviStrauss 1986:140-141), a qual as análises amazônicas corrigem acrescentando uma dimensão concêntrica. ${ }^{18}$

O concentrismo cromatiza o trânsito entre o interior e o exterior: a fronteira diametral entre consanguíneos e afins, entre parentes e inimigos, entre vivos e mortos não é exaustiva, e fica a cargo do canibalismo funerário complementá-la (Vilaça 2000:94-98); é o gradiente de proximidade ou distância em relação ao morto que decide quem é capaz de tratar o cadáver como comida, distanciando-o assim em definitivo dos vivos. Igualmente, o concentrismo transcende o âmbito dessas dicotomias domésticas: a sociologia e o ritual só se completam na cosmologia, como acontece com o canibalismo funerário executado pelos deuses, o que implica também relações de afinidade com eles (Viveiros de Castro 1986). Limitado ao primeiro pólo - o diametral - o canibalismo apenas marcaria fronteiras (come-se o outro); mas a continuidade configura essa relação ao modo de uma fita de moebius, pois aquele que devora o outro se torna outro, abrindo espaço para a alteração e o devir (Viveiros de Castro 1992:303).

No caso do canibalismo bélico, a contrapartida mexicana é inequívoca, especialmente nos seus pontos culminantes: o sacrifício gladiatório, o holocausto massivo de inimigos que se seguia às guerras ou consagrava os grandes templos. Mas o canibalismo funerário está absolutamente ausente 
do universo asteca, seja como prática terrena, seja como destino dos mortos no Além. Em compensação, temos muitas outras festas do calendário em que as vítimas não comparecem como inimigos, e sim em função de outros atributos - crianças de peito "com dois redemoinhos na cabeça", jovens com corpos perfeitos, donzelas - requeridos por um deus em particular.

O pólo "endocanibal" e o "devir outro", a proximidade e a distância conjugam-se aqui; o eixo contínuo, que na Amazônia partia do centro humano em direção à periferia natural ou sobrenatural, estende-se no México em sentido vertical, gerando, no alto e em baixo, áreas em que a divisão entre os próprios e os inimigos ficam borradas. Os cativos deviam ser, ainda neste tipo de sacrifícios, os principais fornecedores de vítimas, mas nem sempre consta esta origem, e sabe-se que em certas ocasiões as vítimas eram escravos locais. A mobilidade ascendente da sociedade asteca - principalmente por méritos de guerra, capturando inimigos - é bem conhecida; ela costumava ser também descendente, podendo se chegar à escravidão em função de uma condenação judicial, ou de modo voluntário, quando um cidadão se agregava a outro mais influente (um recurso comum em épocas de penúria (cf. Tezozomoc 2001:183-ss). As fontes (por exemplo, Hernandez 2000:78-79) detalham o complexo estatuto dos escravos, e as condições que poderiam levar, passo a passo, da simples escravidão à escravidão "sacrificável".

Exógenas ou endógenas - a diferença é aqui privada de significado — as vítimas sobrequalificadas dessas festas não servem diretamente à alimentação do sol predador, mas à produção de deuses. Revestidas com as roupas e os atributos dos deuses, elas são os deuses, e como tais habitam a cidade, às vezes durante longos períodos. Entre os muitos exemplos reunidos por Sahagún, cabe destacar o caso do cativo selecionado para figurar a Tezcatlipoca, o qual exerce esta função por um ano inteiro e recebe quatro parceiras que, na ocasião, encarnam as quatro deusas (Sahagún 1995:115-117), ou a mulher que, encarnando a deusa Toci, é sacrificada e esfolada, passando por sua vez a sacrificar - através do figurante que enverga a sua pele (ibidem:147-149). Guardar por longo tempo a vítima antes do sacrifício, fazendo dela um afim efetivo, como no caso tupinambá, é um modo de identificar o afim e o inimigo. Superficialmente semelhante, a convivência asteca com a vítima cria uma distância entre o centro da sociedade e essa periferia em que é possível, no mesmo movimento, virar escravo e virar deus.

A divindade das vítimas sacrificiais astecas parecerá menos metafórica se observarmos que os deuses astecas são deuses expressamente "produzidos". Para descrevê-los, os informantes de Sahagún não recorrem a uma história sagrada, mas à enumeração das suas alfaias, jóias e funções. Hernandez (2000:164), negando a interpretação corrente dos ídolos astecas 
como representações, assegura que eles são os deuses: "pelo contrário, creio que tinham por deuses as mesmas imagens às quais ouviam muito amiúde responder os que falavam com elas".

Os deuses astecas, à diferença dos deuses araweté, não estão situados no âmbito dos mortos ${ }^{19}$ ou, para falar em termos mais gerais, no Além. Eles estão fundamentalmente na cidade, existem no faustoso cenário criado em torno do sacrifício. Como ídolos esculpidos, são alimentados pelo sangue do sacrifício borrifado sobre eles pelos sacerdotes; como figuras de cereal ou encarnados em cativos e escravos, servem de alimento ao povo em geral ou a alguns membros da elite asteca. No sistema amazônico, a captura do inimigo exterior organiza o universo ao redor do eixo da afinidade e alimenta com ele a produção de consanguíneos e a sociabilidade cotidiana (Fausto 2001:327-328). O complexo sacrificial asteca captura "consanguíneos" externos — os cativos, não esqueçamos, são filhos dos captores — para alimentar o ciclo de guerra e vingança, e com ele a fome cósmica, mas também para alimentar uma diferenciação interna, produzindo deuses e aristocratas sócios de uma troca alimentícia e eventualmente matrimonial. Lembremos do contrato social de Tezozomoc: a sociedade não está completa, ou a rigor carece de nexo até que se incorpora a ela o recurso sacrificial, que liga aliança e consumo no interior de um conjunto vertical, ou que sustenta de fato essa verticalidade. ${ }^{20}$

Dizer que o canibalismo completa ou efetiva a sociedade asteca pode parecer estranho, porque ninguém, desde o primeiro conquistador espanhol, suspeitou que a sociedade asteca precisasse de complementos cosmológicos. O canibalismo asteca tem sido tratado, de praxe, como um canibalismo ajustado a uma estrutura de classes, um excesso ritual causado por um excesso social (o colapso alimentar da superpopulação) ou cultural-ideológico (a necessidade de alimentar o sol insaciável). Deixou de se contemplar o papel estrutural e normal que o canibalismo desempenhou como constituinte dessa sociedade estratificada. Estes parágrafos finais são um aceno para a possibilidade de entender o mundo asteca como uma variante não mais dos modelos feudais ou estatais do Velho Mundo, mas das sociedades selvagens.

Recebido em 24 de setembro de 2008

Aprovado em 05 de março de 2009

Oscar Calavia Sáez é professor do Programa de Pós-Graduação em Antropologia Social, Universidade Federal de Santa Catarina. E-mail: <occs@uol.com.br> 


\section{Notas}

1 "Asteca" é um etnônimo criado no século XVIII pelo antiquário jesuíta Clavijero, que não se encontrará, portanto, nas fontes citadas neste trabalho. Nelas, o leitor se defronta, no entanto, com um emaranhado de etnônimos - mexicas, tenochcas, aculhuas, toltecas, chichimecas etc. - cuja elucidação exigiria uma descrição, de modo algum pacífica, de todo o processo de etnogênese do planalto mexicano. Utilizarei este nome consagrado pelo uso, explicando que com ele me refiro aos habitantes da Tripla Aliança formada pelas polis de Tenochtitlan, Texcoco e Tlacopan (quádrupla aliança, se acrescentássemos também Tlatelolco, a cidade-gêmea de Tenochtitlan, tão fundamental no que vai ser discutido). Esses habitantes, falantes do nahuatl e instalados em torno de uma lagoa situada no que agora é México DF, na virada do século XVI, pouco antes da chegada dos espanhóis, tinham construído uma hegemonia sobre todo o México central. Em várias ocasiões será necessário restabelecer as diferenças, em particular, entre os habitantes de Tenochtitlan e os de Texcoco.

${ }^{2}$ Uma excelente revisão do conjunto da literatura consagrada ao canibalismo pode ser encontrada em Lindenbaum 2004.

${ }^{3}$ Cf. também Obeyesekere e Arens 2003.

${ }^{4} \mathrm{O}$ mesmo prurido por desvincular o ritual do alimentar se reproduz (cf. Vilaça 2000:83-86) no discurso dos etnólogos - e eventualmente no dos nativos - ao tratarem do endocanibalismo funerário amazônico.

${ }^{5}$ Para uma avaliação da obra de Sahagún, cf. Bustamante $(1989,1990)$. Sahagún estava interessado na religião mexicana efetiva, e não no fantasma criado pela fabulação colonial; em outras palavras, levava os astecas a sério. É crítico com as avaliações entusiastas da conversão dos índios e com triunfos do sincretismo, como o culto de Guadalupe, e insiste em reivindicar, contra a opinião derrogatória da época, a valia intelectual e moral dos índios. Cabe ressalvar que sua descrição do mundo asteca está muito condicionada pelo ponto de vista erudito de seus informantes, e pelo seu próprio desígnio de entender as Américas como terra de promissão para o cristianismo.

${ }^{6}$ Nas citações de Sahagún, como nas dos outros cronistas utilizados, acrescento o número do capítulo para facilitar a localização em edições outras que as usadas por mim.

${ }^{7}$ A mesma distância moral entre diferentes performances da ingestão canibal — circunspecta ou prazerosa - aparece nas descrições do canibalismo funerário wari, dentro de um mesmo ritual (Vilaça 1998). A existência de um canibalismo asteca "popular" é no mínimo dúbia. Duverger (1986) sugere que poderia haver, marginalmente, um desvio da carne sacrificial, furtivamente extraída do seu circuito ritual para ser comercializada no mercado para um público mais popular. A hipótese provavelmente 
busca dar conta desses açougues de carne humana no mercado mexicano que alguns cronistas, como Bernal Díaz, citam sem maiores dados em seu apoio.

${ }^{8}$ Fernando de Alvarado Tezozómoc era neto de Moctezuma por parte de mãe, e de um dos seus irmãos por parte de pai; pertencia de fato à mais alta nobreza asteca. Nascido mais ou menos nos anos da conquista espanhola, estava ainda vivo nos inícios do século XVII, e sua trajetória como aristocrata indígena que perdeu lentamente sua posição e se refugiou na glorificação literária do passado é emblemática da elite à qual pertence.

${ }^{9}$ Veja-se o que Pomar - inaugurando a visão popular a respeito da cozinha mexicana — diz a respeito do chili: "Têm ali [pimenta] de sua colheita, de muitos tipos e cores, que comem em todas as suas iguarias, fresca e curada, sem a qual nenhuma comida lhes é agradável e prazerosa"(Pomar 1582, cap. XXIV).

${ }^{10}$ As mulheres escondidas na lagoa, com a água até os peitos, são poupadas pelos astecas vencedores com a condição de "falar como patos", o que elas fazem, assumindo as vozes de vários tipos de ave. A guerra de Tlatelolco é o episódio mais denso e enigmático da crônica de Tezozómoc. Entre os fatores que desencadearam a guerra, estão a vagina falante e profética da rainha de Tlatelolco - uma tenochca que, segundo Ixtlilxóchitl, não agradava a seu marido - e o comportamento desaforado das mulheres tlatelolcas, que ofendem os mexicanos pintando-se e comportando-se como prostitutas, golpeando-se as vaginas e mostrando-lhes o traseiro. O capítulo inteiro tem um inefável sabor freudiano pela evidência do registro sexual, e por tudo acontecer por assim dizer em família. Se Texcoco e Tacuba, cidades aliadas, estavam ligadas a Tenochtitlan por laços tão estreitos que seus habitantes "não são menos do que primos" (Pomar 1582), Tlatelolco pode ser entendida mais como a "metade" da polis mexicana (Bueno Bravo 2005), o que permite interpretar esse conflito como uma contribuição mexicana à reflexão sobre os perigos da aliança.

${ }^{11}$ Os mercadores, de fato, organizam um ritual canibal integrado ao ciclo comum sacerdotal-guerreiro, mas claramente autônomo - vale a pena lembrar que Sahagún (1995) o descreve num capítulo à parte distanciado dos outros — cuja principal diferença consiste em se abastecer não de guerreiros capturados em combate, mas de escravos comprados. Duverger (1986) analisa o modo com que esse ritual, e a classe que o efetiva, compete e até certo ponto se integra ao ciclo sacrificial aristocrático dos sacerdotes e dos militares.

${ }^{12}$ Tal como Pomar descreve essa longa peregrinação da carne dos sacrificados, é fácil lembrar do estoicismo com que os Wari enfrentavam o dever de ingerir a carne de um parente morto, estragada durante a longa preparação do ritual funerário (Vilaça 1998).

${ }^{13}$ Métraux (1928) sintetiza as descrições quinhentistas do ritual sacrificial tupinambá. Remeto também aos comentários de Carneiro da Cunha e Viveiros de Castro (1985) e de Viveiros de Castro (1986, 1992). 
${ }^{14}$ Em casos excepcionais, aparecem também dois elementos essenciais no tratamento da vítima tupinambá: a sua coabitação com parceiras locais e a adoção do seu nome pelo seu captor; em geral, porém, o inimigo não é elaborado como afim, e sim como filho. Vd. Infra nota 26.

${ }^{15}$ Eventualmente, se a vítima consegue resistir a eles com sucesso, um quinto guerreiro, canhoto, é chamado para concluir a provação.

${ }^{16}$ Como acontece também no Peru, é útil comparar as descrições dos grandes cronistas do século XVI, caudatários do discurso das elites indígenas, com as versões muito mais "populares" recolhidas cem anos depois pelos extirpadores de idolatrias (Bernand \& Gruzinski 1992).

${ }^{17}$ Tomo aqui a licença de falar em "Amazônia" para evitar um circunlóquio tão longo como "Terras Baixas da América do Sul". A melhor justificativa é teórica: embora possa envolver povos da costa brasileira ou do centro do continente, os conceitos e as linhas de análise a que me refiro procedem de etnografias realizadas na bacia amazônica.

${ }^{18}$ Aplico ao canibalismo o contraste entre diametral e concêntrico que Viveiros de Castro (1993) toma de Lévi-Strauss para discutir os sistemas dravidianos da Amazônia. Nesses termos gerais, o par diametral-concêntrico significa apenas que uma divisão binária e categórica (nós/outros, por exemplo) se complementa com um gradiente centro-periferia.

${ }^{19}$ Estes se encontram numa série de destinos especializados - céus, paraísos, infernos — distribuídos em função do modo com que morreram.

${ }^{20} \mathrm{O}$ ponto é bem mais complexo, e para ser desenvolvido precisaria de um longo exame do parentesco mexicano, aqui impossível. Mas parece claro que a afinidade não tem no México a potência organizadora que tem na Amazônia. À diferença dos deuses araweté, os deuses astecas não são necessariamente afins; a coabitação da vítima-Tezcatlipoca com quatro parceiras-deusas, ou o da vítima-Ixcozauhqui com uma moça pública (Sahagún 1995, cap. 176) não é a norma para outros sacrifícios, e em qualquer caso não configuram uma aliança matrimonial entre os deuses e os astecas. O casamento "vertical" que Tezozómoc cita em seu contrato canibal não corresponde à prática habitual de matrimônios dentro das classes; os conflitos com Tlatelolco citados na nota 10 são conflitos entre afins, mas se enunciam como conflitos entre "primos" ou entre esposos. 


\section{Referências bibliográficas}

ACOSTA, José. 2002. Historia natural y moral de las Índias. Madrid: Dastin. ARENS, William. 1979. The man-eating myth. New York: Oxford University Press.

. 2003. "Cannibalism reconsidered: responses to Marshall Sahlins. Anthropology Today, 19(5):18-19.

BATAILLE, Georges. 1967. La part maudite. Paris: Minuit.

BERNAND, Carmen \& GRUZINSKI, Serge 1992. De la idolatria. Una arqueologia de las ciencias religiosas. México: Fondo de Cultura Econômica.

BUENO BRAVO, Isabel. 2005. "Tlatelolco: la gemela en la sombra". Revista Española de Antropología Americana, 35:133-148.

BUSTAMANTE, Jesús. 1990. Fray Bernardino de Sahagún. Una revision crítica de los manuscritos y de su proceso de composición. México, DF: Universidad Nacional Autónoma de México. · 1989: "Fray Bernardino de Sahagún o la necesidad de actuar desde el conocimiento". In: José Luis Peset (org.), Ciencia, vida y espacio en Iberoamérica. vol. I. Madrid: CSIC. pp.179-192.

CARNEIRO DA CUNHA, Manuela. \& VIVEIROS DE CASTRO, Eduardo. 1985. "Vingança e temporalidade: os Tupinambá". Journal de la Société des Américanistes, 71:129-208.

DUVERGER, Christian. 1986. La flor letal. Economia del sacrifício azteca. México: Fondo de Cultura Econômica.

FAUSTO, Carlos. 2001. Inimigos fiéis: história, guerra e xamanismo na Amazônia. São Paulo: EdUSP.

GRAULICH, Michel. 1982. "Tlacaxipehualiztli ou la fête aztèque de la moisson et de la guerre". Revista Española de Antropologia Americana, XII :215-254.
HARNER, Michael. 1977. "The ecological basis for aztec sacrifice". American Ethnologist, 4:117-135.

HARRIS, Marvin. 1977. Cannibals and kings: the origins of culture. New York: Random House.

HERNÁNDEZ, Francisco. 2000. Antigüedades de la Nueva España. Madrid: Dastin.

ISAAC, Barry. L. 2005. "Aztec cannibalism. Nahua versus spanish and mestizo accounts in the valley of México". Ancient Mesoamerica, 16:1-10.

IXTLILXOCHITL, Fernando de Alva. 2000. Historia de la nación Chichimeca. Madrid: Dastin.

LAFAYE, Jacques. 1977. Quetzalcoatl y Guadalupe. La formación de la conciencia nacional en México. México: Fondo de Cultura Económica.

LESTRINGANT, François. 1994. Le cannibale, grandeur et décadence. Paris: Perrin.

LÉVI-STRAUSS, Claude. 1986. "Canibalismo e disfarce ritual". In: Minhas palavras. São Paulo: Brasiliense. pp. 140-148.

LINDENBAUM, Shirley. 2004. "Thinking about cannibalism". Annual Review of Anthropology, 33:475-498.

MÉTRAUX, Alfred. 1928. La religion des Tupinamba et ses rapports avec celle des autres tribus Tupi-Guarani. Bibliothèque de l'École des Hautes Études XLV. Paris: Leroux.

MOLINIÉ, Antoinette. 2001. "Das sociedades amazônicas ao estado inca: os modelos de relação mito-rito e seu sistema de transformação". ILHA, 3(1):5-23.

OBEYESEKERE, Gananath. 2005. Cannibal talk: the man-eating myth and human sacrifice in the South Seas. Berkeley: University of California Press. 
— \& ARENS, William. 2003. "Cannibalism reconsidered responses to Marshall Sahlins". Anthropology Today, 19(5):18-19.

ORTIZ de MONTELLANO, Bernard. R. 1978. "Aztec cannibalism: an ecological necessity?". Science, 200:511-617.

PETRINOVICH, Lewis. 2000. The cannibal within. New York: Aldine De Gruyter.

POMAR, Juan Bautista. 1582. Relación de tezcoco. Biblioteca del Grupo de Etnologia Americana.http://www. etnologiamericana.org/view/download/Juan\%20Bautista\%20Pomar\%2 C\%20Relaci\%F3n\%20de\%20Tezcoco $\% 20 \% 281582 \% 29$.doc

RENARD CASEVITZ, France Marie; SAIGNES, Thierry \& TAYLOR, AnneChristine. 1986. L'Inca, l'espagnol et les sauvages. Rapports entre les societés amazoniennes et andines du XVè au XVIIè siécle. Paris: Ed. Recherches sur les Civilisations.

SAHAGÚN, Bernardino de. 1995. História general de las cosas de Nueva España. Madrid: Alianza Editorial.

SAHLINS, Marshall. 1978. "Culture as protein and profit". New York Review of Books, 25(18):45-53. . 1979. "Cannibalism: an exchange". New York Review of Books, 26(4):45-47. - 2003. "Artificially maintained controversies: global warming and the fidjian cannibalism". Anthropology Today, 19(3):3-5.

TEZOZOMOC, Hernando de Alvarado. 2001. Crónica mexicana. Madrid: Dastin.

VILAÇA, Aparecida. 1998. "Fazendo corpos: reflexões sobre morte e canibalismo entre os Wari' à luz do perspectivismo". Revista de Antropologia, 41(1):09-67. - 1992. Comendo como gente: formas do canibalismo wari' . Rio de Janeiro: UFRJ-ANPOCS.
- 2000. "Relations between funerary cannibalism and warfare cannibalism: the question of predation". Ethnos, 51(1):83-106.

VIVEIROS DE CASTRO, Eduardo. 1986. Araweté: os deuses canibais. Rio de Janeiro: Zahar. . 1992. From the enemy's point of view. Chicago: University of Chicago Press.

. 1993. "Alguns aspectos da afinidade no dravidianato amazônico". In: \& Manuela Carneiro da Cunha (org.), Amazônia: etnologia e história indígena. São Paulo: NHII/USP/FAPESP. pp. 149-210.

. 1998. "Cosmological deixis and amerindian perspectivism". Journal of the Royal Anthropological Institute, 4(3):469-488. 
Resumo

O canibalismo asteca tem sido objeto de numerosas interpretações que o caracterizaram em termos ecológicos, culturais ou simbólicos, ou como uma peça de propaganda colonial. Uma revisão das fontes mais conhecidas - espanholas, indígenas ou mestiças - mostra que essa procura de explicações abrangentes foi reducionista. Passou por alto a complexidade das fontes, nas quais o canibalismo aparece como um objeto heterogêneo, prescrito ou nefando, dependendo da sua qualificação, dotado de um extenso significado sociológico e apontando para versões divergentes da cosmologia. O artigo propõe também uma comparação entre o canibalismo asteca e os seus equivalentes na costa brasileira e na Amazônia que mostra sua coincidência numa cosmologia transformacional.

Palavras-chave Canibalismo, Sacrifício, Asteca, Tupi, Amazônia

\section{Abstract}

Aztec cannibalism has been the object of numerous interpretations that have characterized it in ecological, cultural or symbolic terms, or as a piece of colonial propaganda. A revision of the most widely known Spanish, Indigenous and Mestizo sources shows that this quest for wide-ranging explanations has been reductionist. The complexity of the sources, in which cannibalism, depending on its qualification, emerges as a heterogeneous, prescriptive or nefarious object, endowed with extensive sociological meaning and pointing towards divergent versions of cosmology, has been largely overlooked. The article also proposes a comparison between Aztec cannibalism and its equivalent along the Brazilian coast and in Amazonia, which attests to its coincidence in a transformational cosmology.

Key words Cannibalism, Sacrifice, Aztec, Tupi, Amazonia 